\title{
DIAGNOSIS PENYEBAB PENYAKIT BARU GUGUR DAUN KARET (Hevea brasiliensis Muell. Arg.)
}

\author{
Diagnosis of Causal Agent of New Rubber Leaf Fall Disease \\ (Hevea brasiliensis Muell. Arg)
Alchemi Putri Juliantika KUSDIANA ${ }^{1^{*}}$, Meity Suradji SINAGA ${ }^{2}$, dan Efi Toding TONDOK ${ }^{2}$
${ }^{1}$ Mahasiswa Fitopatologi, Sekolah Pascasarjana, Institut Pertanian Bogor Jalan Kamper, Babakan, Dramaga, Bogor, Jawa Barat 16680
*Email: alchemiputri@gmail.com

\begin{abstract}
${ }^{2}$ Staf Pengajar Departemen Proteksi Tanaman, Fakultas Pertanian, Institut Pertanian Bogor Jalan Kamper, Babakan, Dramaga, Bogor, Jawa Barat 16680
\end{abstract}

Diterima: 22 Oktober 2020 / Disetujui : 24 November 2020

\begin{abstract}
One of the causal of the low rubber production is the presence of plant diseases. Leaffall disease in rubber plants is the major disease, after white root disease. Currently, there is an incidence of new rubber leaf fall disease with different symptoms from the diseases previously reported in rubber plantations. This disease is widespread in Sumatra, Bangka Belitung, Kalimantan, and Southeast Asia. There are many suspicions about the causal agent, but there is no accurate diagnosis of the causal agent. Therefore, this research was carried out to determine the causal agents of leaf fall disease with symptoms of round leaf spots that can cause leaf fall. The diagnosis was carried out using Koch's postulate by isolating the pathogen from several rubber clones, inoculating the pathogen to healthy rubber plants, re-isolating from inoculated plants, and confirming pathogenic species through morphologically and molecularly identification with the rDNA-ITS sequence. Based on the results of Koch's postulates and morphological and molecular identification, the causal agent of leaf fall disease in rubber plants is the fungus Pestalotiopsis microspora (Speg.) G. C. Zhao \& N. Li. Furthermore, a new rubber leaffall disease is called Pestalotiopsis leaffall disease.
\end{abstract}

Keywords: Koch postulate; ITS r-DNA; Pestalotiopsis microspora

\section{Abstrak}

Salah satu penyebab rendahnya produksi karet yaitu adanya gangguan penyakit tanaman. Penyakit gugur daun pada tanaman karet merupakan kendala utama, setelah penyakit jamur akar putih. Saat ini, terdapat kejadian penyakit gugur daun karet baru dengan gejala yang berbeda dengan penyakit yang sebelumnya ditemukan di perkebunan karet. Penyakit ini menyebar di wilayah Sumatera, Bangka Belitung, Kalimantan, dan Asia Tenggara. Banyak dugaan penyebab penyakit, namun sampai saat ini belum terdapat diagnosis yang akurat mengenai patogen gugur daun karet. Oleh karena itu, penelitian ini dilakukan untuk mendeterminasi penyebab penyakit gugur daun baru dengan gejala bercak berbentuk bulat dan dapat mengakibatkan gugur daun. Diagnosis dilakukan dengan postulat Koch yaitu dengan cara isolasi patogen dari beberapa klon karet, inokulasi patogen pada tanaman karet sehat, re-isolasi dari tanaman yang diinokulasi patogen, serta konfirmasi spesies patogen melalui identifikasi morfologi dan molekuler dengan sekuen rDNA-ITS. Berdasarkan hasil postulat Koch serta identifikasi secara morfologi dan molekuler, penyebab gugur daun baru pada tanaman karet yaitu cendawan Pestalotiopsis microspora (Speg.) G. C. Zhao $\&$ N. Li. Selanjutnya, penyakit gugur daun karet yang baru disebut penyakit gugur daun Pestalotiopsis. 
Kata kunci: Pestalotiopsis microspora; postulat Koch; rDNA-ITS

\section{PENDAHULUAN}

Produksi tanaman karet dipengaruhi oleh beberapa faktor seperti jenis klon, cara budidaya, lingkungan, dan gangguan dari berbagai penyakit. Penyakit pada tanaman karet terdapat pada semua stadia pertumbuhan karet, seperti tanaman entres, tanaman pembibitan, tanaman belum menghasilkan, dan tanaman menghasilkan. Sebagian besar penyakit penting pada tanaman karet memiliki gejala tajuk meranggas, seperti penyakit jamur akar putih, kanker batang, serta gugur daun.

Penyakit gugur daun karet yang umumnya terdapat di Indonesia disebabkan oleh cendawan Colletotrichum gloeosporioides (Penz.) Sacc., Oidium heveae B.A. Steinm., dan Corynespora cassiicola (Berk \& Curt) Wei. Gugur daun Colletotrichum pertama kali dilaporkan di Indonesia pada tahun 1918. Gejala pada daun muda adalah daun mengeriput, menggulung, ujung daun mati, dan gugur. Gejala pada daun tua terdapat bercak kecil berwarna hitam, berlubang, dan bagian ujung mati. Serangan berat menyebabkan gugur daun dan tajuk meranggas (Shufen et al., 1999). Gugur daun Oidium pertama kali dilaporkan di Indonesia pada tahun 1938. Pada permukaan daun terdapat lapisan putih seperti tepung yang merupakan massa konidia cendawan. Daun yang terserang terlihat pucat, mengering, dan serangan berat mengakibatkan daun gugur (Suryaningtyas, 2012). Gugur daun Corynespora pertama kali dilaporkan di Indonesia pada tahun 1980. Gejala pada daun karet terdapat bercak seperti sirip ikan dan warna daun menjadi kuning atau cokelat kemudian gugur (Situmorang et al., 2004).

Sejak akhir tahun 2017, ditemukan gejala penyakit baru yang menyebabkan gugur daun di perkebunan karet wilayah
Sumatera dengan keparahan penyakit yang tinggi. Penyakit tersebut memiliki gejala yang berbeda dengan penyakit gugur daun yang sebelumnya telah dilaporkan. Pengamatan awal menunjukkan gejala berupa bercak daun berbentuk bulat berwarna cokelat muda dan cokelat tua. Pada setiap helai daun terdapat satu bercak atau lebih. Gejala bercak terdapat pada daun berwarna hijau sampai hijau tua berumur lebih dari 1 bulan. Daun yang terserang patogen dapat mengalami perubahan warna menjadi kuning atau oranye. Patogen dapat menyerang semua jenis klon dan infeksi berat dapat menyebabkan daun karet menjadi gugur lebih dari 90\% (Febbiyanti \& Fairuzah, 2020).

Berdasarkan press release Direktorat Jenderal Perkebunan, penyakit ini telah menyebar ke beberapa wilayah Indonesia, seperti Bangka Belitung, Kalimantan Barat, Kalimantan Tengah, dan Kalimantan Selatan dengan luasan yang terserang sebesar 381,9 ribu hektar. Pada tahun yang sama, gejala penyakit ini juga ditemukan di beberapa sentra karet di Johor, Malaysia (Zambri et al., 2018). Setelah itu, beberapa negara penghasil karet di kawasan Asia Tenggara seperti India, Sri Lanka, dan Thailand juga melaporkan gejala penyakit yang sama.

Adanya kejadian penyakit gugur daun di wilayah Sumatera tersebut dapat menurunkan produksi lateks hingga 45\% (Febbiyanti \& Fairuzah, 2020). Pada umumnya penurunan produksi lateks akibat penyakit gugur daun dapat mencapai $7 \%$ sampai $45 \%$ tergantung dari keparahan penyakit (Pawirosoemardjo, 2004). Penurunan produksi tersebut dapat menurunkan juga capaian produktivitas nasional serta pendapatan petani dan pelaku usaha karet.

Banyak dugaan jenis patogen gugur daun ini, seperti disebabkan oleh Fusicoccum sp. (Febbiyanti et al., 2018), Colletotrichum spp. (Philip et al., 2019; 
Rodesuchit, 2020), dan Pestalotiopsis sp. (Zambri et al., 2018; Febbiyanti \& Fairuzah, 2020), namun sampai saat ini belum ada diagnosis yang tepat sebagai penyebab penyakit yang ditunjukkan dengan keberhasilan postulat Koch. Aturan untuk mengkonfirmasi bahwa suatu organisme merupakan penyebab suatu penyakit dikenal dengan postulat Koch. Adapun pernyataan Koch adalah patogen yang diduga harus selalu berasosiasi pada tanaman yang sakit. Patogen tersebut harus dapat diisolasi dan ditumbuhkan sebagai biakan murni yang apabila diinokulasikan ke tanaman sehat menghasilkan gejala dan tanda penyakit yang sama. Apabila penyebab penyakit dilakukan reisolasi akan menghasilkan biakan murni yang sama dengan biakan murni awal (Grimes, 2006). Apabila salah satu dari pernyataan tersebut tidak ditemukan maka diagnosis dikatakan belum tepat. Selain itu, konfirmasi hasil dari postulat Koch dilakukan analisis molekuler. Diagnosis penyakit tanaman yang akurat sangat penting dilakukan untuk pengelolaan penyakit tanaman yang efisien dan ekonomis. Diagnosis yang tidak akurat dapat menyebabkan kegagalan dalam strategi pengendalian penyakit yang dapat menyebabkan kehilangan hasil dan kerugian secara ekonomi (Balodi et al., 2017). Oleh karena itu, penelitian ini dilakukan untuk mendeterminasi patogen baru gugur daun pada tanaman karet.

\section{BAHAN METODE}

Penelitian dilaksanakan dari bulan September 2019 sampai Juni 2020. Kegiatan isolasi dan identifikasi patogen berdasarkan karakter morfologi dilakukan di Laboratorium Mikologi Tumbuhan, Departemen Proteksi Tanaman, IPB. Kegiatan ekstraksi DNA dan amplifikasi fragmen DNA dengan teknik PCR dilakukan di Laboratorium Fisiologi Pusat Penelitian Karet. Kegiatan inokulasi patogen pada bibit karet dilakukan di rumah kaca Pusat Penelitian Karet, Sumatera Selatan.
Diagnosis gugur daun karet dilakukan dengan postulat Koch dan konfirmasi spesies patogen dilakukan dengan identifikasi morfologi dan molekuler. Adapun rangkaian kegiatan sebagai berikut:

\section{Pengambilan Sampel Tanaman Sakit}

Sampel tanaman sakit diambil dari 4 klon karet di Kebun Percobaan Pusat Penelitian Karet, Sumatera Selatan. Penentuan sampel klon karet berdasarkan hasil pengamatan di lapangan yaitu klon yang resisten (RRIC 100), klon moderat (PB 260), serta klon rentan (BPM 24 dan GT 1). Sampel tanaman yang diambil berupa daun yang memiliki gejala bercak bulat berwarna cokelat muda atau cokelat tua.

\section{Isolasi Cendawan Patogen dari Tanaman Sakit}

Isolasi cendawan patogen dari tanaman sakit dilakukan dengan memotong daun dengan ukuran $\pm 0,5 \mathrm{~cm}^{2}$ di antara bagian jaringan yang sakit dan jaringan yang sehat. Setelah itu, dilakukan sterilisasi permukaan dengan menggunakan $\mathrm{NaOCl}$ $1 \%$ selama 30 detik, alkohol $70 \%$ selama 30 detik, dan dibilas dengan menggunakan akuades steril sebanyak 3 kali, kemudian dilanjutkan dengan penanaman jaringan pada media potato dextrose agar (PDA). Cendawan yang tumbuh dibiakkan dan dimurnikan pada media yang sama sampai diperoleh biakan murni.

\section{Isolasi Spora Tunggal Cendawan Patogen}

Isolasi spora tunggal dilakukan menggunakan metode Maharachchikumbura et al. (2012) yang dimodifikasi. Konidiomata cendawan patogen direndam dalam $5 \mathrm{~mL}$ aquades steril dan dibiarkan beberapa menit. Sebanyak $100 \mu \mathrm{L}$ suspensi konidia dimasukkan ke dalam cawan petri berisi media water agar (WA) dan diinkubasi pada suhu $25^{\circ} \mathrm{C}$ selama $18-24$ jam sampai konidia berkecambah. Apabila konidia telah berkecambah, dilakukan pemindahan pada media PDA dengan menggunakan jarum 
steril untuk mengambil bagian agar yang mengandung konidia. Media PDA yang telah diberi spora diinkubasi pada suhu $25^{\circ} \mathrm{C}$ selama 7-10 hari sampai koloni tumbuh.

\section{Inokulasi Cendawan Patogen pada Tanaman Karet}

Penelitian yang dilakukan menggunakan rancangan acak lengkap (RAL) dengan perlakuan inokulasi patogen menggunakan beberapa jenis klon karet yaitu RRIC 100, PB 260, BPM 24, dan GT 1. Sumber inokulum yang digunakan pada postulat Koch berupa potongan miselia biakan murni ukuran $5 \mathrm{~mm}^{2}$. Setiap jenis klon karet diinokulasi dengan miselium cendawan yang berasal dari klon yang sama. Sebagai kontrol dilakukan inokulasi media PDA. Inokulasi patogen dilakukan dengan cara menempelkan potongan biakan miselia pada bagian bawah daun yang sebelumnya telah dilukai. Setelah itu, miselia ditutup dengan kapas steril lembap (Gambar 1). Daun yang digunakan merupakan daun hijau muda berumur 4 minggu. Pengamatan dilakukan setiap hari sampai gejala bercak muncul. Pengamatan yang dilakukan berupa insidensi penyakit serta keparahan penyakit dengan kriteria skoring disajikan pada Tabel 1.

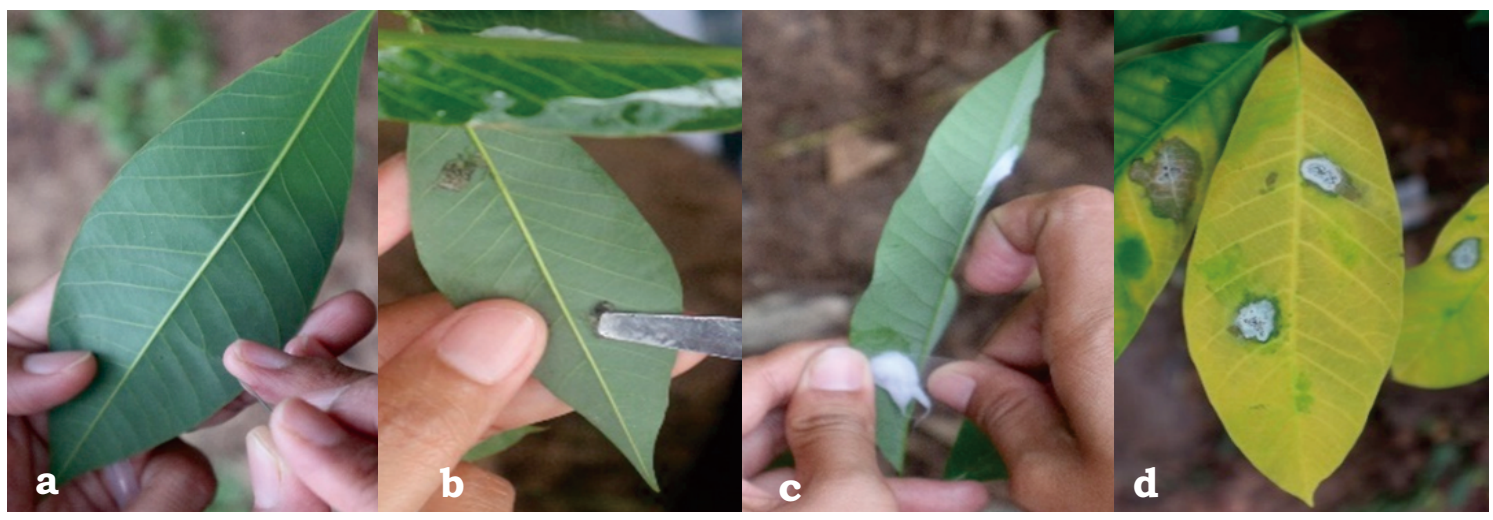

Gambar 1. Tahapan inokulasi cendawan patogen. a) pelukaan daun, b) penempelen miselium patogen, c) pemberian kapas steril lembab, dan d) pengamatan gejala penyakit

Figure 1. Stages of inoculation of pathogenic fungi. a) leaf injury, b) penetrating pathogenic mycelium, c) giving moist sterile cotton, and d) observing disease symptoms

Tabel 1. Skoring keparahan penyakit gugur daun karet

Table 1. Scoring of leaf fall disease severity

\begin{tabular}{cl}
$\begin{array}{c}\text { Skor } \\
\text { Score }\end{array}$ & \multicolumn{1}{c}{$\begin{array}{c}\text { Deskripsi gejala } \\
\text { Description of symptoms }\end{array}$} \\
\hline 0 & Tanaman tidak bergejala \\
1 & Muncul titik bercak tapi tidak berkembang \\
2 & Bercak berdiameter 1 mm sampai $3 \mathrm{~mm}$ \\
3 & Bercak berdiameter $3,1 \mathrm{~mm}$ sampai $5 \mathrm{~mm}$ \\
4 & Bercak berdiameter $5,1 \mathrm{~mm}$ sampai $7 \mathrm{~mm}$ \\
5 & Bercak berdiameter $>7,1 \mathrm{~mm}$ atau daun mulai berubah warna menjadi oranye \\
6 & Daun berubah warna menjadi oranye \\
7 & Daun gugur \\
\hline
\end{tabular}


Berdasarkan hasil dari penilaian skor penyakit, dilakukan perhitungan keparahan penyakit dengan rumus Towsend dan Heuberger (1974) dalam Sinaga (2006) sebagai berikut:

Keparahan penyakit $=\frac{\sum_{i=1}^{n}\left(n_{i} \cdot v_{i}\right)}{\mathrm{N} \cdot \mathrm{V}} \cdot 100 \%$

Dimana (remaks):

$\mathrm{n}=$ jumlah tanaman yang terserang pada kategori i

$\mathrm{v}=$ kategori kerusakan ke-i

$\mathrm{N}=$ jumlah tanaman yang diamati

$\mathrm{V}=$ jumlah kategori serangan tertinggi

Adapun rumus untuk menghitung insidensi penyakit sebagai berikut:

$$
\text { Insidensi penyakit }=\frac{\mathrm{n}}{\mathrm{N}} \cdot 100 \%
$$

Dimana (remaks):

$\mathrm{n}=$ jumlah tanaman yang terserang

$\mathrm{N}=$ jumlah tanaman yang diamati

Data hasil perhitungan keparahan dan insidensi penyakit selanjutnya dianalisis menggunakan sidik ragam pada taraf 5\%. Apabila terdapat pengaruh nyata dilakukan uji lanjut menggunakan uji jarak berganda Duncan pada taraf $5 \%$ menggunakan program Statistical Analysis System (SAS) 9.

\section{Re-isolasi Cendawan Patogen}

Re-isolasi cendawan yang menimbulkan gejala bercak daun dari hasil uji postulat Koch dilakukan dengan metode yang sama seperti isolasi cendawan patogen di awal yaitu dengan memotong daun berukuran $\pm 0,5 \mathrm{~cm}^{2}$ di antara bagian jaringan yang sakit dan jaringan yang sehat. Setelah itu, dilakukan sterilisasi permukaan dengan menggunakan $\mathrm{NaOCl} 1 \%$ selama 30 detik, alkohol 70\% selama 30 detik, dan dibilas dengan menggunakan akuades steril sebanyak 3 kali, kemudian dilanjutkan dengan penanaman jaringan pada media PDA. Cendawan yang tumbuh dibiakkan dan dimurnikan pada medium yang sama sampai diperoleh biakan murni.

\section{Identifikasi Cendawan Patogen}

Identifikasi Morfologi dan Mikroskopis. Identifikasi cendawan patogen dilakukan dengan mengamati karakter morfologi yang muncul pada sampel bagian tanaman sakit dari lapangan maupun hasil isolasi dan re-isolasi. Identifikasi dilakukan berdasarkan morfologi koloni (laju pertumbuhan, bentuk koloni, dan warna koloni) dengan pengamatan langsung dan bantuan penggaris, serta morfologi tanda patogen (bentuk konidia, ukuran konidia, jumlah sel, dan jumlah setula) dengan menggunakan mikroskop compound Olympus BX41 dan aplikasi image-pro express. Identifikasi dilakukan dengan menggunakan kunci identifikasi menurut Maharachchikumbura et al. (2011).

Identifikasi Molekuler. Ekstraksi DNA dari isolat cendawan patogen dilakukan dengan menumbuhkan isolat pada $100 \mathrm{~mL}$ medium potato dextrose broth (PDB) dalam tabung erlenmeyer, kemudian digoyang dengan kecepatan 1.500 rpm pada suhu $25^{\circ} \mathrm{C}$ selama 7 hari. Miselia yang tumbuh digerus dan digunakan untuk ekstraksi DNA. Ekstraksi DNA menggunakan prosedur yang dikembangkan oleh Doyle \& Doyle (1990) berbasis cetyl trimethyl ammonium bromide (CTAB). Miselia hasil penggerusan dimasukkan ke dalam tabung eppendorf dan ditambahkan buffer ekstraksi (2\% b/v CTAB, 100 mM Tris-HCl pH 8, 20 mM EDTA pH 8, 1,4 M NaCl), lalu diinkubasi pada suhu $65^{\circ} \mathrm{C}$ selama 10 menit dengan sesekali dilakukan pengocokan, kemudian diikuti dengan menambahkan fenol: kloroform: isoamyl alkohol dengan perbandingan volume 25:24:1. Sampel disentrifugasi pada kecepatan $10.000 \mathrm{rpm}$ selama 10 menit. Supernatan hasil sentrifugasi dipindahkan ke tabung yang baru. DNA kemudian diendapkan dengan menambahkan 1 kali volume isopropanol dingin dan perlahan tabung diputar lalu diinkubasi pada suhu $-20^{\circ} \mathrm{C}$ selama 1 jam. Setelah itu, dilakukan sentrifugasi kembali 
dengan kecepatan $16.000 \mathrm{rpm}$ selama 10 menit pada suhu $4^{\circ} \mathrm{C}$. Supernatan dicuci dengan menggunakan etanol $70 \%$ dan dikeringkan-anginkan pada suhu kamar. Supernatan DNA dilarutkan dalam $50 \mathrm{~mL}$ air suling steril dan disimpan pada suhu $-20^{\circ} \mathrm{C}$.

Amplifikasi DNA untuk melihat keragaman sekuen ITS rDNA menggunakan pasangan primer universal cendawan primer ITS1 (5'-TCCGTAGGTGAACCTGCGG-3') dan ITS4 (5'-TCCTCCGCTTATTGATATGC-3'). Komponen dan komposisi bahan PCR terdiri atas $15,3 \mu \mathrm{L}$ ddH2O, $2,5 \mu \mathrm{L}$ buffer $10 \mathrm{x}+$ $\mathrm{Mg} 2+, 2,5 \mu \mathrm{L}$ sucrose cresol 10x, 0,5 $\mu \mathrm{L}$ dNTP $10 \mathrm{mM}$, masing-masing $1 \mu \mathrm{L}$ primer forward dan reverse, $0,2 \mu \mathrm{L}$ enzim Taq DNA polimerase rekombinan $5 \mathrm{U} / \mu \mathrm{L}$, dan $2 \mu \mathrm{L}$ DNA sampel, sehingga volume campuran reaksi menjadi $25 \mu \mathrm{L}$. Program amplifikasi terdiri atas denaturasi awal $\left(94^{\circ} \mathrm{C}, 90\right.$ detik), diikuti 40 siklus pemanasan denaturasi $\left(95^{\circ} \mathrm{C}, 35\right.$ detik), anealing $\left(55^{\circ} \mathrm{C}, 55\right.$ detik), dan ekstensi $\left(72^{\circ} \mathrm{C}, 60\right.$ detik). Ekstensi akhir dilakukan pada suhu $72^{\circ} \mathrm{C}$ selama 10 menit (Jasalavich et al., 2000). Amplikon DNA dielektroforesis pada gel agarosa $1 \%$ pada tegangan $55 \mathrm{~V}$ selama 50 menit. Pita DNA divisualisasi pada transiluminator UV.

Pengamatan urutan sekuen fragmen DNA dilakukan dengan sekuensing melalui First Base International Ltd., Malaysia. Susunan nukleotida dari setiap isolat yang diperoleh diidentifikasi dengan program Basic Local Alignment Search Tool (BLAST) yaitu membandingkan dengan database yang terdapat pada Genbank dalam situs National Centre for Biotechnology Information (NCBI) (http://www.ncbi.nlm.nih.gov /blast/Blast.cgi). Setelah itu, hasil sekuensing di alignment dengan sekuen DNA cendawan yang tersedia di GenBank (Pestalotiopsis microspora asal Thailand (KX020561), Malaysia (MK801280), Korea (DQ456865), Jepang (GU908473), Cina (KT965676, MK333971, dan MT322831), serta P. theae (AY681481), P. chamaeropis (LC412070), P. camelliae (NR120188), dan Corynespora cassiicola (KP759967) sebagai out grup). Analisis filogenetik dari sekuen DNA cendawan tersebut dilakukan dengan metode neighbour joining tree dalam bootstrap 1000 ulangan menggunakan program Mega X 10.1.

\section{HASIL DAN PEMBAHASAN}

Penyakit gugur daun karet di lapangan menunjukkan gejala yang khas yaitu bercak berbentuk bulat tidak beraturan berwarna cokelat muda sampai cokelat tua dengan pinggiran berwarna lebih gelap. Pada permukaan bercak berkembang aservuli berwarna hitam. Pada setiap helai daun terdapat lebih dari satu bercak (Gambar 2a). Gejala terlihat pada daun berwarna hijau sampai hijau gelap berumur lebih dari 1 bulan. Selain itu, daun juga mengalami perubahan warna menjadi kuning kemerahan. Serangan lanjut dapat mengakibatkan terjadinya gugur daun. Gugur daun dapat terjadi pada daun yang mengalami perubahan warna maupun daun yang masih berwarna hijau tua. Tidak terdapat perbedaan gejala yang signifikan antar jenis klon karet.

Berdasarkan hasil isolasi daun dari 4 klon karet serta identifikasi isolat secara morfologi dan mikroskopis menunjukkan bahwa cendawan yang tumbuh adalah Pestalotiopsis sp. Cendawan tersebut dilakukan inokulasi pada tanaman karet stadia daun hijau dengan metode penempelan miselium cendawan menggunakan pelukaan. Metode tersebut dipilih karena Pestalotiopsis sp. dianggap sebagai patogen lemah (Maharachchikumbura et al., 2011) yang menembus inang melalui lubang alami seperti stomata, lentisel, dan hidatoda (Agrios, 2005).

Setiap klon menunjukkan respon gejala berupa bercak berbentuk bulat tidak beraturan berwarna cokelat muda dengan pinggiran bercak berwarna lebih gelap. Pada permukaan bercak juga berkembang aservuli berwarna hitam (Gambar 2a-e). Gejala bercak terlihat pada 3 hari setelah inokulasi (hsi). Pada klon RRIC 100 dan GT 1 terjadi perubahan warna menjadi kuning pada hari ketiga setelah inokulasi dan 

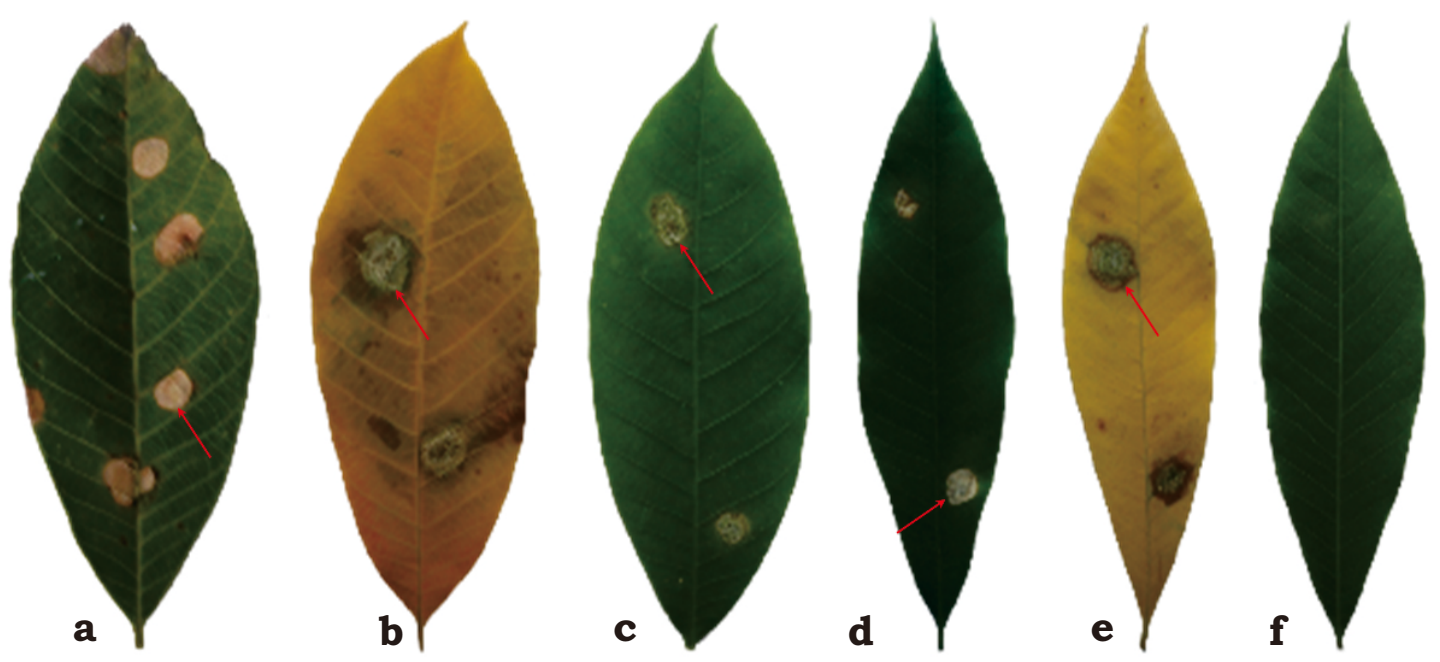

Gambar 2. Gejala bercak daun dari lapangan berbentuk bulat tidak beraturan berwarna cokelat dengan pinggiran bercak berwarna lebih gelap (a), gejala pada daun yang diinokulasi Pestalotiopsis sp. pada klon RRIC 100 (b), PB 260 (c), BPM 24 (d), GT 1 (e), dan daun pada perlakuan kontrol (f)

Figure 2. Symptoms of leaf spot from the field are round irregularly shaped brown with darker colored fringes (a), symptoms on leaves inoculated with Pestalotiopsis sp. on clones RRIC 100 (b), PB 260 (c), BPM 24 (d), GT 1 (e), and control treatment (f)

mengalami gugur daun pada hari kelima setelah inokulasi. Hasil pengamatan di lapangan juga menunjukkan terdapat perubahan warna menjadi kuning atau oranye pada daun yang terserang patogen. Hal tersebut dapat disebabkan adanya pengaruh toksin yang membantu serangan patogen. Beberapa cendawan patogen dapat memproduksi fitotoksin yang dapat mengganggu fungsi sel inang atau membunuh sel sebelum atau selama proses infeksi patogen (Agrios, 2005). Beberapa spesies Pestalotiopsis dilaporkan menghasilkan metabolit sekunder bioaktif yang membantu hubungan antara inang dan patogen, seperti $P$. longiseta dan $P$. theae penyebab penyakit hawar daun kelabu teh menghasilkan 3 fitotoksin yaitu oxysporone, epiepoxydon, dan PT-toxin (Nagata et al., 1992); P. guepinii penyebab hawar cabang kacang hazel menghasilkan pestalopyrone (Turkkan et al., 2011); dan P. oenotherae penyebab bercak daun pada Oenothera laciniata menghasilkan oxysporone (Venkatasubbaiah, Dyke, \& Chilton, 1991).
Perubahan warna daun menjadi kuning dan absisi daun juga dapat disebabkan oleh produksi hormon pada tanaman seperti etilen dan asam absisat (ABA). Selain dihasilkan secara alami oleh tumbuhan, hormon juga dihasilkan oleh cendawan. Patogen dapat mengganggu pertumbuhan inang dengan memproduksi hormon penyebab respon abnormal dari inang dan memproduksi senyawa yang menstimulasi tumbuhan inang untuk memproduksi hormon tumbuh lebih banyak atau lebih sedikit. Hormon etilen merupakan fitohormon multifungsi yang mengatur pertumbuhan dan penuaan daun. Proses penuaan daun dapat menjadi respon pertahanan terhadap infeksi patogen yang terlihat dengan nekrosis sel daun atau perubahan warna akibat degradasi klorofil dan diikuti dengan kematian sel daun (Ferrante \& Francini, 2006). Hormon ABA tidak berperan secara langsung dalam proses pengguguran daun, namun hormon ini berperan dalam menyebabkan penuaan pada sel-sel daun sebelum daun gugur dan 
hal tersebut dapat menyebabkan terjadinya peningkatan produksi etilen (Asra, et al. 2020).

Gejala bercak dengan aservuli berwarna hitam menyebar pada daun karet hasil postulat Koch menunjukkan persamaan dengan gejala awal yang diamati di lapangan (Gambar 3). Selain itu, hasil inokulasi cendawan Pestalotiopsis sp. pada beberapa klon karet menunjukkan persentase keparahan penyakit yang tinggi yaitu lebih dari $50,00 \%$ dengan kejadian penyakit lebih dari $83,33 \%$. Hasil analisis statistika menunjukkan bahwa klon RRIC 100 dan GT 1 memiliki nilai keparahan dan insidensi penyakit lebih tinggi dibandingkan klon lainnya, walaupun keparahan penyakit pada klon RRIC 100 tidak berbeda nyata dengan semua klon (Tabel 2). Diameter bercak pada daun hasil inokulasi memiliki nilai yang bervariasi yaitu berkisar antara 2 $\mathrm{mm}$ sampai $14 \mathrm{~mm}$. Hasil pengukuran diameter bercak dari beberapa klon karet di lapangan juga menunjukkan hasil yang hampir sama yaitu berkisar antara $3 \mathrm{~mm}$ sampai $16 \mathrm{~mm}$ dengan rata-rata diameter bercak sebesar $8,10 \mathrm{~mm}$. Hal tersebut disampaikan juga oleh Chen et al. (2018) bahwa spesies Pestalotiopsis penyebab penyakit hawar daun kelabu pada tanaman teh berhasil diinokulasi melalui metode pelukaan dengan kejadian penyakit antara $41,70 \%$ sampai $76,70 \%$ dan diameter lesi sebesar 3,30 $\mathrm{mm}$ sampai 10,80 $\mathrm{mm}$, sedangkan pada daun yang diinokulasi tanpa pelukaan tidak menghasilkan gejala.

\section{Karakter Koloni Cendawan Patogen}

Karakter makroskopis Pestalotiopsis sp. pada media PDA berupa koloni berwarna putih, bertekstur halus, berbentuk seperti bunga atau membentuk pola lingkaran, dan terdapat konidiomata berwarna hitam yang mulai tumbuh pada hari ke 4 hingga hari ke 13 setelah isolasi (Gambar 4). Konidiomata Pestalotiopsis sp. dapat tumbuh secara
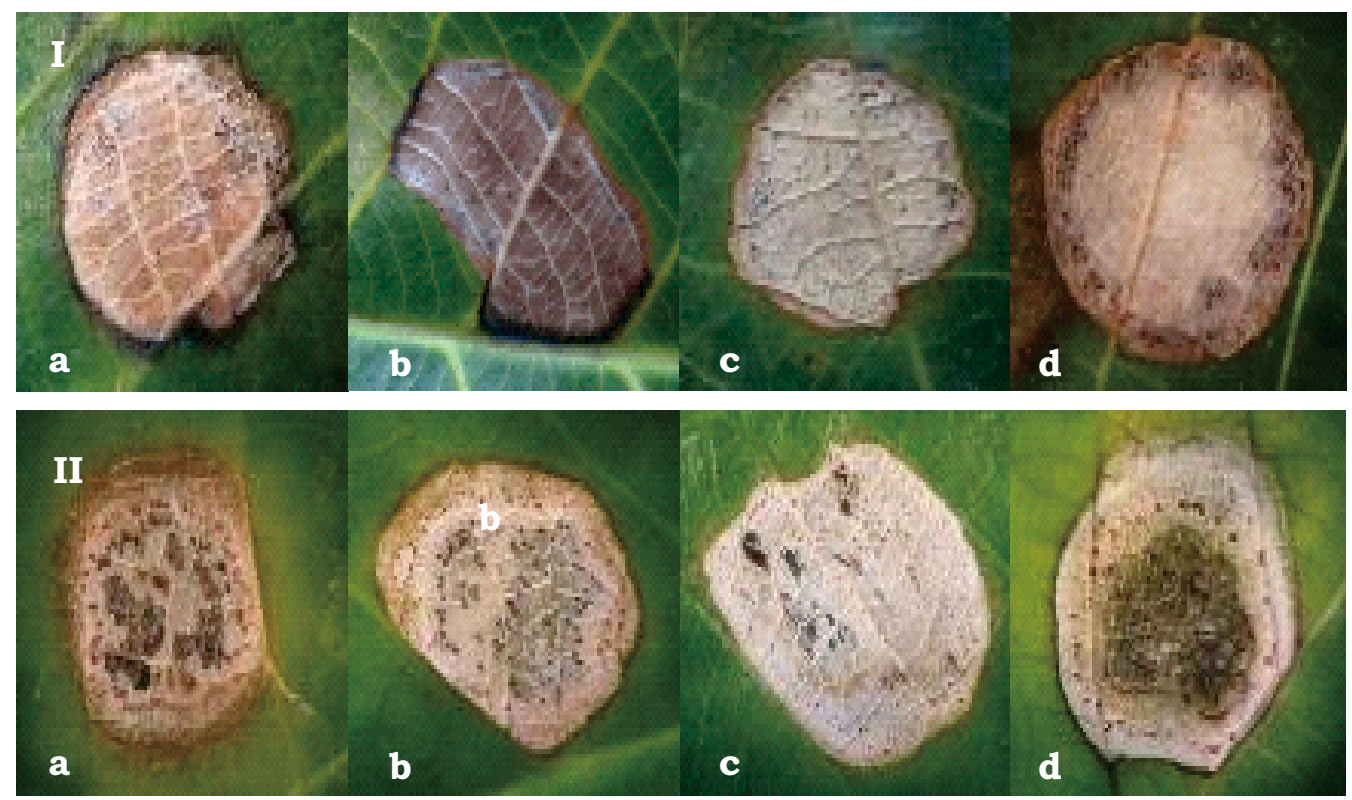

Gambar 3. Bercak pada permukaan atas daun dari lapangan (I) dan bercak pada permukaan atas daun yang diinokulasi Pestalotiopsis sp. (II), pada klon RRIC 100 (a), PB 260 (b), BPM 24 (c), dan GT 1 (d)

Figure 3. Spots on the adaxial of the leaves from field (I) and spots on the adaxial of the leaves inoculated with Pestalotiopsis sp. (II), on the RRIC 100 (a), PB 260 (b), BPM 24 (c), and GT 1 (d) clones 
Tabel 2. Keparahan dan insidensi penyakit gugur daun pada 7 hari setelah inokulasi (hsi) Table 2. Severity and incidence of leaf fall disease at 7 days after inoculation (dai)

\begin{tabular}{|c|c|c|}
\hline $\begin{array}{l}\text { Perlakuan } \\
\text { Treatment }\end{array}$ & $\begin{array}{c}\text { Keparahan } \\
\text { penyakit } \\
\text { Disease severity } \\
(\%)\end{array}$ & $\begin{array}{l}\text { Insidensi penyakit } \\
\text { Disease incidence } \\
(\%)\end{array}$ \\
\hline Klon RRIC 100 - Inokulasi Pestalotiopsis sp. & $65,61 \mathrm{ab}$ & 94, \\
\hline Klon PB 260 - Inokulasi Pestalotiopsis sp. & $50,00 \mathrm{~b}$ & 83 , \\
\hline Klon BPM 24 - Inokulasi Pestalotiopsis sp. & $53,70 \mathrm{~b}$ & $83,33 \mathrm{~b}$ \\
\hline Klon GT 1 - Inokulasi Pestalotiopsis sp. & 79,89 a & $100,00 \mathrm{a}$ \\
\hline Kontrol & $0,00 \mathrm{c}$ & $0,00 \mathrm{c}$ \\
\hline \multicolumn{3}{|l|}{ Keterangan } \\
\hline \multicolumn{3}{|c|}{$\begin{array}{l}\text { Number followed with different letter at the same coloum showed significantly } \\
\text { different based on Duncan at } 5 \% \text { level. }\end{array}$} \\
\hline
\end{tabular}
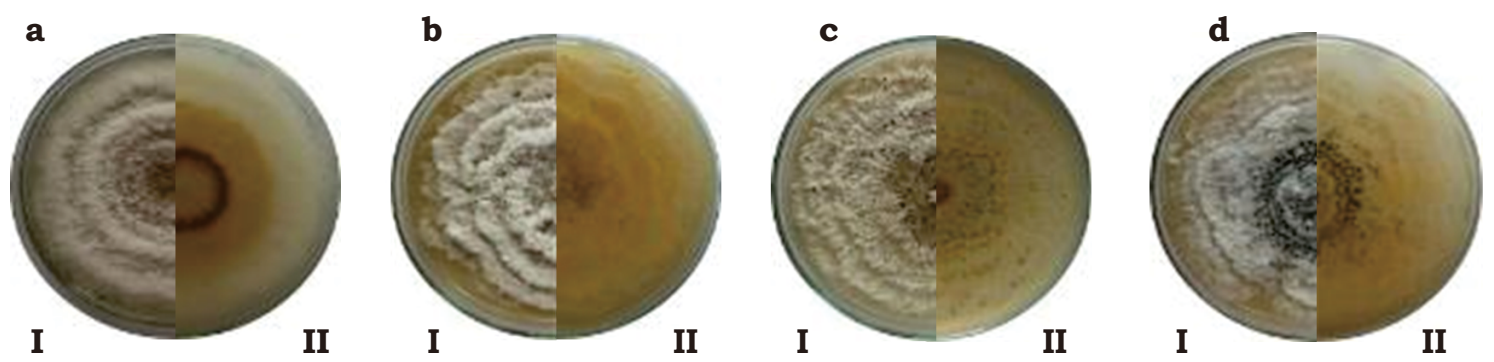

Gambar 4. Karakter koloni cendawan Pestalotiopsis sp. asal beberapa klon karet dengan pola melingkar pada isolat asal RRIC 100 (a) serta pola seperti bunga pada isolat asal PB 260 (b), BPM 24 (c), dan GT 1 (d). (I: permukaan atas koloni dan II: permukaan bawah cawan petri)

Figure 4. The character of Pestalotiopsis sp. from several rubber clones with circular patterns on isolates from RRIC 100 (a) and flower-like patterns in isolates from PB 260 (b), $B P M 24$ (c), and GT 1 (d). (I: the upper surface of the colony and II: the lower surface of the petridish)

radial, menyebar tidak teratur, dan berpusat pada bagian tengah koloni (Espinoza et al., 2008). Cendawan mencapai diameter $8 \mathrm{~cm}$ setelah 7 hari pada suhu $25^{\circ} \mathrm{C}$.

Berdasarkan bentuk konidianya, Steyaert (1949) dalam (Maharachchikumbura et al., 2014) membagi Pestalotia menjadi 3 genus yaitu Pestalotia, Pestalotiopsis, dan Truncatella. Truncatella untuk spesies dengan konidia bersel 4, Pestalotiopsis untuk konidia bersel 5, dan Pestalotia untuk konidia bersel 6 .
Selanjutnya Pestalotiopsis dibagi menjadi beberapa bagian berdasarkan jumlah setula yaitu monosetula, bisetula, trisetula, dan multisetula. Selain itu, Pestalotiopsis juga dikelompokkan berdasarkan warna pada pigmen sel median konidianya yaitu berwarna seragam dan tidak seragam (Jeewon et al., 2004).

Berdasarkan hasil pengamatan mikroskopis, konidia yang diperoleh berbentuk fusiform hingga oval dengan ukuran berkisar antara 13,21 $\mu \mathrm{m}-16,15 \mu \mathrm{m}$ 
x 2,36 $\mu \mathrm{m}-4,70 \mu \mathrm{m}$ (Tabel 3). Konidia terdiri atas 5 sel dengan 4 septa yang berwarna lebih gelap dibandingkan sel median. Sel median berjumlah 3 dan berwarna cokelat muda sampai cokelat tua. Sel basal dan apikal berwarna hialin dan berbentuk seperti kerucut. Pada setiap konidia memiliki setula yang muncul pada ujung apikal berjumlah 2-4 buah dengan ukuran panjang 10,81 $\mu \mathrm{m}$ - 15,95 $\mu \mathrm{m}$ dan berwarna hialin, sedangkan pada setiap ujung sel basal muncul pedisel berbentuk tabung dan berwarna hialin (Gambar 5).
Maharachchikumbura et al., (2011) melaporkan karakteristik konidia tersebut mirip dengan P. microspora (Speg.) G.C. Zhao $\&$ N. Li. Selain itu, Han et al. (2019) melaporkan konidiomata dari P. microspora berbentuk bundar, berwarna hitam, berlendir dan berkilau, serta memiliki diameter $120 \mu \mathrm{m}$ hingga $410 \mu \mathrm{m}$. Sel konidia P. microspora berbentuk fusiform sampai oval, hialin, pendek, dan berdinding tipis. Sel basal dan sel apikal berbentuk segitiga dan hialin. Zhang, Wu, Tsukiboshi, \& Okabe

Tabel 3. Karakteristik konidia P. microspora asal beberapa klon Table 3. Characteristics of P. microspora conidia from several clones

\begin{tabular}{|c|c|c|c|}
\hline \multirow{2}{*}{$\begin{array}{c}\text { P. microspora } \\
\text { Asal Klon } \\
\text { P. microspora from } \\
\text { clones }\end{array}$} & \multirow{2}{*}{$\begin{array}{c}\text { Ukuran Konidia } \\
\text { Conidia Size } \\
\text { Panjang x Lebar } \\
\text { Length } x \text { Width } \\
(\mu \mathrm{m})\end{array}$} & \multicolumn{2}{|c|}{$\begin{array}{c}\text { Setula } \\
\text { Appendages }\end{array}$} \\
\hline & & $\begin{array}{l}\text { Jumlah } \\
\text { Amount }\end{array}$ & $\begin{array}{l}\text { Panjang } \\
\text { Length } \\
(\mu \mathrm{m})\end{array}$ \\
\hline RRIC 100 & $14,71 \pm 0,80 \times 4,01 \pm 0,31$ & $2-4$ & $13,01 \pm 1,32$ \\
\hline PB 260 & $13,54 \pm 0,21 \times 3,74 \pm 0,44$ & $2-4$ & $13,20 \pm 1,20$ \\
\hline BPM 24 & $14,03 \pm 0,40 \times 3,61 \pm 0,52$ & $2-4$ & $13,01 \pm 0,55$ \\
\hline GT 1 & $14,17 \pm 0,85 \times 3,56 \pm 0,59$ & $2-4$ & $13,42 \pm 0,82$ \\
\hline
\end{tabular}
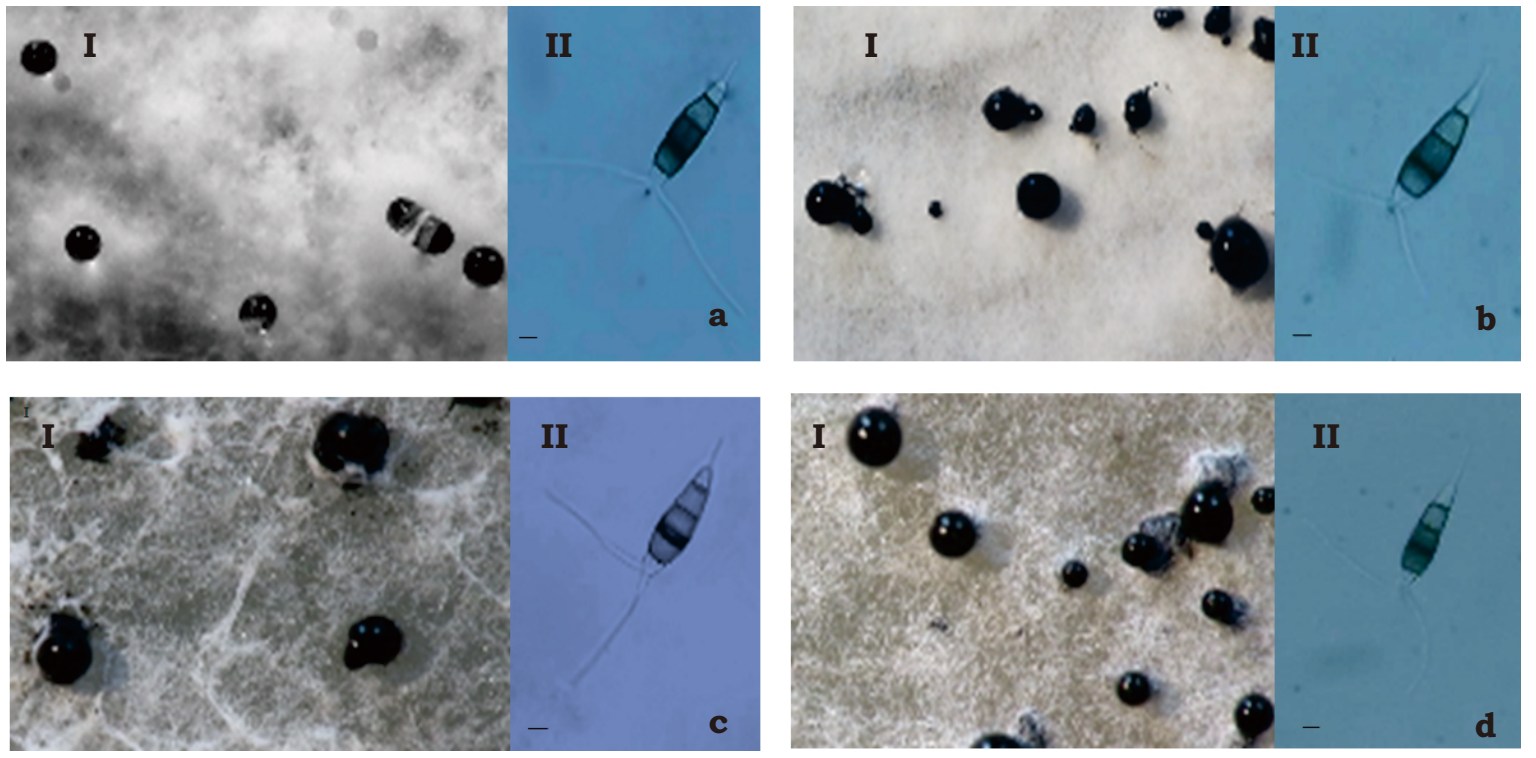

Gambar 5. Konidiomata (I) dan konidia (II) Pestalotiopsis sp. asal klon karet RRIC 100 (a), PB 260 (b), BPM 24 (c), dan GT 1 (d) pada perbesaran 1000x (scale bars $=2 \mu \mathrm{m}$ )

Figure 5. Conidiomata (I) and conidia (II) Pestalotiopsis sp. from rubber clones RRIC 100 (a), PB 260 (b), BPM 24 (C), and GT 1 (d) at 1000x magnification (scale bars $=2 \mu \mathrm{m}$ ) 
(2010) menyebutkan ukuran konidia P. microspora asal Hypericum patulum berkisar antara $17 \mu \mathrm{m}-21 \mu \mathrm{m} \times 5 \mu \mathrm{m}-8 \mu \mathrm{m}$ dengan ukuran setula berkisar antara $10 \mu \mathrm{m}$ $-21 \mu \mathrm{m}$.

\section{Identifikasi Molekuler Cendawan Patogen}

Konfirmasi hasil identifikasi morfologi dan mikroskopis dari 4 isolat $P$. microspora asal karet dilakukan dengan identifikasi molekuler. Hasil BLAST pada GenBank menunjukkan bahwa sekuens ITS dari 4 isolat asal klon karet memiliki kemiripan lebih dari 99\% dengan P. microspora (Tabel 4).

Berdasarkan pohon filogeni dari 4 isolat $P$. microspora asal karet (Gambar 6) menunjukkan isolat inang karet asal Indonesia berada pada kelompok yang sama dengan isolat-isolat $P$. microspora yang merupakan patogen pada beberapa inang dan berasal dari negara yang berbeda, sedangkan dengan isolat Pestalotiopsis spesies lain berada dalam kelompok yang berbeda. Hal ini menunjukkan isolat P. microspora asal karet Indonesia memiliki

Tabel 4. Homologi nukleotida isolat cendawan asal klon karet dengan P. microspora yang tersedia di GenBank dengan program BLAST

Table 4. Nucleotide homology of fungal isolates from rubber clones with P. microspora at GenBank with the BLAST program

\begin{tabular}{lccc}
\hline $\begin{array}{c}\text { Isolat Asal } \\
\text { Klon } \\
\begin{array}{c}\text { Clone Origin } \\
\text { Isolates }\end{array}\end{array}$ & $\begin{array}{c}\text { Homologi } \\
\text { Homology } \\
(\%)\end{array}$ & $\begin{array}{c}\text { Nomor Aksesi GenBank } \\
\text { GenBank Accession Number }\end{array}$ & $\begin{array}{c}\text { Asal Negara } \\
\text { Country of Origin }\end{array}$ \\
\hline RRIC 100 & 99,63 & MH707063.1 & Cina \\
PB 260 & 99,81 & MH707065.1 & Cina \\
BPM 24 & 99,82 & MH707065.1 & Cina \\
GT 1 & 99,63 & MH707065.1 & Cina \\
\hline
\end{tabular}

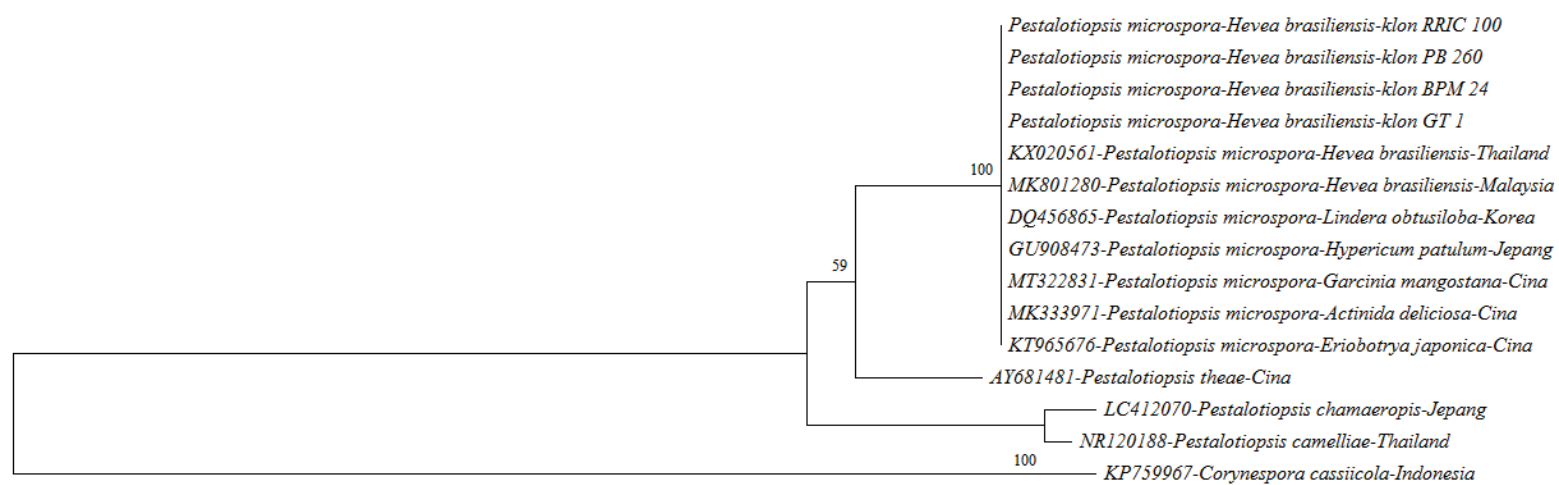

0,050

Gambar6. Pohon filogenetik sekuen nukleotida $P$. microspora dengan metode neighbour joining tree

Figure 6. Phylogenetic tree of P. microspora nucleotide sequences using a neighboring joining tree method 
hubungan kekerabatan yang dekat dengan isolat $P$. microspora dari negara lain berdasarkan sekuen DNA.

Berdasarkan hasil penularan cendawan Pestalotiopsis sp. pada kegiatan postulat Koch menunjukan gejala bercak yang sama dengan bercak yang terdapat pada daun di lapangan yaitu bercak berbentuk tidak beraturan, berwarna cokelat muda dengan pinggiran bercak berwarna lebih gelap, serta terdapat aservuli berwarna hitam yang menyebar pada permukaan bercak. Selain itu, hasil reisolasi daun sakit asal postulat Koch menunjukkan miselium, konidiomata, dan konidia yang sama dengan hasil isolasi daun sakit yang diambil dari lapangan. Hasil konfirmasi spesies dengan molekuler menunjukkan jenis spesies yang sama. Hal ini menandakan bahwa patogen penyebab gugur daun karet yaitu Pestalotiopsis microspora.

\section{KESIMPULAN}

Berdasarkan hasil identifikasi secara morfologi dan molekuler, penyebab gugur daun baru pada tanaman karet dengan gejala bercak berbentuk bulat tidak beraturan berwarna cokelat dengan pinggiran berwarna lebih gelap yaitu cendawan Pestalotiopsis microspora (Speg.) G.C. Zhao \& N. Li. Selanjutnya, penyakit gugur daun ini disebut dengan penyakit gugur daun Pestalotiopsis. Hasil penelitian ini memberikan informasi mengenai spesies penyebab penyakit gugur daun baru pada tanaman karet. Hal tersebut menjadi dasar bagi para peneliti untuk mengembangkan penelitian lanjutan terkait karakter bioekologi patogen atau pengembangan strategi pengendalian penyakit.

\section{DAFTAR PUSTAKA}

Agrios, G. (2004). Plant pathology: Fifth edition. In Plant Pathology : Fifth Edition (Vol. 9780080473). https://doi.org/10.1016/C2009-002037-6
Asra, R., Samarlina, R. A., \& Silalahi, M. (2020). Hormon Tumbuhan. Jakarta: UKI Press

Balodi, R., Bisht, S., Ghatak, A., \& Rao, K. H. (2017). Plant disease diagnosis: Technological advancements and challenges. Indian Phytopathology, 70(3), 275-281. https://doi.org /10.24838/ip.2017.v70.i3.72487

Chen, Y., Zeng, L., Shu, N., Jiang, M., Wang, H., Huang, Y., \& Tong, H. (2018). Pestalotiopsis-like species causing gray blight disease on Camellia sinensis in China. Plant Disease, 102(1), 98-106. https://doi.org / 10.1094/PDIS-05-17-0642-RE

Doyle, J J, \& Doyle, J. L. (1990). Isolation of plant DNA from fresh tissue. Focus, $12,13-15$.

Espinoza, J. G., Briceño, E. X., Keith, L. M., \& Latorre, B. A. (2008). Canker and twig dieback of blueberry caused by Pestalotiopsis spp. and a Truncatella sp. in Chile. Plant Disease, 92(10), 1407-1414. https://doi.org / 10.1094/PDIS-92-10-1407

Febbiyanti, T. R., Kusdiana, A. P. J, Fairuzah, Z, \& Herlinawati, E. (2018). The outbreak of Fusicoccum leaf disease in Indonesia and the potential yield loss. International Plant Protection Workshop 2018.

Febbiyanti, T. R., \& Fairuzah, Z. (2020). Identifikasi Penyebab Kejadian Luar Biasa Penyakit Gugur Daun Karet di Indonesia. Jurnal Penelitian Karet, 37(2), 193-206. https://doi.org / 10.22302/ppk.jpk.v37i2.616

Ferrante, A., Francini, A. (2006). Ethylene and leaf senescence. In N. A. Khan (Ed.), Ethylene Action in Plants (pp. 51-67). Springer. https://doi.org / 10.1007/978-3-540-32846-9 
Grimes, D. J. (2006). Koch's Postulates-Then and Now. 1(5), 223-228.

Han, S., Wang, Y., Wang, M., Li, S., Ruan, R., Qiao, T., \& Zhu, T. (2019). First report of Pestalotiopsis microspora causing leaf blight disease of Machilus nanmu in China. The American Phytopathological Society. https://doi.org/10.1094/PDIS-0519-0937-PDN

Jasalavich, C. A., Ostrofsky, A., \& Jellison, J. (2000). Detection and identification of decay fungi in spruce wood by restriction fragment length polymorphism analysis of amplified genes encoding rRNA. Applied and Environmental Microbiology, 66(11), 4725-4734. https://doi.org / 10.1128 / AEM.66.11.47254734.2000

Jeewon, R., Liew, E. C. Y., \& Hyde, K. D. (2004). Phylogenetic evaluation of s pecies nomenclature of Pestalotiopsis in relation to host association. Fungal Diversity, 17(May 2014), 39-55.

Maharachchikumbura, S. S.N., Hyde, K. D., Groenewald, J. Z., Xu, J., \& Crous, P. W. (2014). Pestalotiopsis revisited. Studies in Mycology, 79(1), 121-186. https://doi.org/10.1016/j.simyco.2 014.09.005

Maharachchikumbura, Sajeewa S.N., Guo, L. D., Cai, L., Chukeatirote, E., Wu, W. P., Sun, X., Crous, P. W., Bhat, D. J., McKenzie, E. H. C., Bahkali, A. H., \& Hyde, K. D. (2012). A multi-locus backbone tree for Pestalotiopsis, with a polyphasic characterization of 14 new species. Fungal Diversity, 56(1), 95-129. https: / / d o i.org / 10.1007/s13225-012-0198-1

Maharachchikumbura, Sajeewa S.N., Guo, L. D., Chukeatirote, E., Bahkali, A. H., \& Hyde, K. D. (2011). Pestalotiopsis-morphology, phylogeny, biochemistry and diversity. Fungal Diversity, 50 ( J a n u a r y ), $167-187$. https://doi.org/10.1007/s 13225011-0125-x
Nagata, T., Ando, Y., \& Hirota, A. (1992). Phytotoxins from Tea Gray Blight Fungi, Pestalotiopsis longiseta and Pestalotiopsis theae. Bioscience, Biotechnology and Biochemistry, 56(5), 810-811. https://doi.org / $10.1271 /$ bbb. 56.810

Pawirosoemardjo, S. (2004). Manajemen pengendalian penyakit penting dalam upaya mengamankan target produksi karet nasional tahun 2020. Prosiding Pertemuan Teknis, 21-45.

Philip, S., Prem, E., \& Vineeth, V. K. (2019). New leaf spot disease of rubber. IRRDB Plant Breeder's Meeting.

Rodesuchit, A. (2020). Current situation on the new leaf fall disease in Thailand. Meeting of Expert on Pestalotiopsis LeafDisease.

Shufen, F., Gang, G., \& Fucong, Z. (1999). General situation of anthracnose of rubber trees and its researches in China. Proceedings of IRRDB Symposium 1999, 288-297.

Situmorang, A., Sinaga, M. S., Suseno, R., Hidayat, S. H., Siswanto, Darussamin, A. (2004). Status dan manajemen pengendalian penyakit gugur daun Corynespora di perkebunan karet. Prosiding Pertemuan Teknis, 97-118.

Suryaningtyas, H. (2012). Pengendalian penyakit. In M. Lasminingsih (Ed.), Sapta Bina Usahatani Karet Rakyat (pp. 67-80). Balai Penelitian Sembawa, Pusat Penelitian Karet.

Turkkan, M., Andolfi, A., Zonno, M. C., Erper, I., Perrone, C., Cimmino, A., Vurro, M., \& Evidente, A. (2011). Phytotoxins produced by Pestalotiopsis guepinii, the causal agent of hazelnut twig blight. Phytopathologia Mediterranea, 50, 154-158. 
Venkatasubbaiah, P., \& Van Dyke, C. G. (1991). Phytotoxins produced by Pestalotiopsis oenotherae, a pathogen of evening primrose. Phytochemistry, 30(5), 1471-1474. https://doi.org / 10.1016/0031-9422(91)84189-Y

Zambri, A. M. A., Mahyudin, M. M., \& Noran, A. S. (2018). Re-Emergence of Hevea leaf spot caused by Pestolotia sp. in Malaysia. Proceeding International Plant Protection Workshop 2018.
Zhang, M., Wu, H. Y., Tsukiboshi, T., \& Okabe, I. (2010). First report of Pestalotiopsis microspora causing leaf spot of hidcote (Hypericum patulum) in Japan. Plant Disease, 94(8), 1064. https://doi.org /10.1094/PDIS-948-1064B. 